\title{
Table of EU/EC policy documents (in chronological order)
}

Communication from the Commission of the European Communities, Green Paper on copyright and the challenge of technologycopyright issues requiring immediate action, Brussels, 7 June 1988, COM (88) 172 final 15

Follow-up to the Green Paper on copyright and the challenge of technology. Working programme of the Commission in the field of copyright and neighbouring rights, Brussels, 17 January 1991, COM (90) 584 final 16

European Commission, White Paper on Growth, competitiveness, employment. The challenges and ways forward into the $21^{\text {st }}$ century, Brussels, 5 December 1993, COM (93) 700, Bulletin of the European Communities, Supplement 6/93 16

Communication from the Commission to the Council and the European Parliament and to the Economic and Social Committee of Regions, Europe's way to the information society: an action plan, Brussels, 19 July 1994, COM (94) 347 final

European Commission, Growth, competitiveness and employment. White Paper follow-up, Europe and the global information society. Recommendations of the high-level group on the information society to the Corfu
European Council (Bangemann Group), Bulletin of the European

Union, Supplement 2/94 17

Communication from the Commission of the European Communities Green Paper on Copyright and Related Rights in the Information Society, Brussels, 19 July 1995, COM (95) 382 final

Communication from the Commission, Follow-up to the Green Paper on Copyright and Related Rights in the Information Society, 20 November 1996, COM (1996) 568 final 18

Report from the Commission to the Council, the European Parliament and the Economic and Social Committee on the implementation and effects of Directive 91/250/ EEC on the legal protection of computer programs, Brussels, 10 April 2000, COM(2000) 199 final 65

Communication from the Commission to the Council, the European Parliament and the European Economic and Social Committee, The management of copyright and related rights in the internal market, Brussels, 19 April 2004, COM/2004/0261 final

Commission Staff Working Paper on the review of the EC legal framework in the field of copyright and related rights, 19 July 2004, SEC(2004) 995 $21,61,98,227$ 
DG Internal Market and Services Working Paper, First evaluation of Directive 96/9/EC on the legal protection of databases, Brussels, 12 December 2005 .... 66, 67, 161

Communication from the Commission to the European Parliament, the Council, the European Economic and Social Committee and the Committee of the Regions, $A$ Single Market for the $21^{\text {st }}$ Century Europe, 20 November 2007, COM (2007) 725 final ...... 3, 22, 30,32, $35,36,40$

Communication from the Commission of the European Communities, Green Paper on Copyright in the Knowledge Economy, 16 July 2008, COM (2008) 466/3 22

Communication from the Commission, Copyright in the Knowledge Economy, Brussels, 19 October 2009, COM (2009) 532 final $20,22,23$

Reflection Document of DG INFSO and DG MARKT on Creative Content in a European Digital Single Market: Challenges for the Future, 22 October 2009 24

Communication from the Commission, Europe 2020 - A strategy for smart, sustainable and inclusive growth, Brussels, 3 March 2010, COM (2010) 2020 final .... 33, 40

Communication from the Commission to the European Parliament, the Council, the Economic and Social Committee and the Committee of the Regions, Towards a Single Market Act For a highly competitive social market economy-50 proposals for improving our work, business and exchanges with one another, Brussels, 27 October 2010, COM (2010) 608 final 30,32

Commission Staff Working Document, European Competitiveness Report
2010, Accompanying document to the Communication from the Commission to the European Parliament, the Council, the European Economic and Social Committee and the Committee of the Regions, An integrated Industrial Policy for the Globalisation Era Putting Competitiveness and Sustainability at the Front Stage, Brussels, 28 October 2010, SEC (2010) 1276 final, Volume I, 11

Communication from the Commission to the European Parliament, the Council, the Economic and Social Committee and the Committee of the Regions, Single Market ActTwelve levers to boost growth and strengthen confidence - 'Working together to create new growth', Brussels, 13 April 2011, COM (2011) 206 final ....... 3, 30, 31, 32

Communication from the Commission to the European Parliament, the Council, the European Economic and Social Committee of the Regions, A Single Market for intellectual property rights boosting creativity and innovation to provide economic growth, high quality jobs and first class products and services in Europe, Brussels, 24 May 2011, COM (2011) 287 final 3,30

Commission Communication to the European Parliament, the Council, the Economic and Social Committee and the Committee of the Regions, A coherent framework for building trust in the Digital Single Market for e-commerce and online services, Brussels, 11 January 2012,

$\operatorname{COM}(2011) 942$ $40,42,46$ 
Conclusions of the European Council,

CO EUR 4 CONCL 2, Brussels,

29 June 2012, EUCO 76/12 ..... 41

European Parliament resolution of 11

September 2012 on the online distribution of audiovisual works

in the European Union, 2011/

2313(INI)
Communication from the

Commission, On content in the Digital Single Market, Brussels, 18 December 2012, COM (2012)

789 final 37,39 